\title{
Does Mannose-Binding Lectin Gene Polymorphism in Pediatric Patients Undergoing Peritoneal Dialysis Cause Susceptibility to the Development of Peritonitis?
}

\section{Gültaç Evren ๑ Mustafa Bak $\odot$ Erkin Serdaroğlu ( Burak Durmaz $\odot$ Ferda Özkinay $\odot$}

\author{
Periton Diyalizi Yapılan Çocuk Hastalarda Mannoz \\ Bağlayan Lektin Gen Polimorfizmi, Peritonit \\ Gelişimine Yatkınlık Oluşturur mu?
}

\section{ABSTRACT}

Objective: This study aims to investigate the relationship between peritonitis attacks and mannosebinding lectin (MBL) gene polymorphism in patients undergoing peritoneal dialysis.

Method: Codon 54 polymorphism found in exon 1 of the MBL gene was investigated by polymerase chain reaction-restriction fragment length polymorphism method in 45 patients with chronic renal failure undergoing peritoneal dialysis.

Results: The frequency of the mutant B allele was not significantly higher in the patient group (4.4\%) than the control group (2.1\%). The AB genotype was found at a rate of $15.6 \%$ and $34 \%$ in the patient group and healthy control group, respectively. The AA genotype was found in $80 \%$ of children who underwent peritoneal dialysis and $63.8 \%$ of the healthy control group.

Conclusion: In our study, no relationship was found between peritonitis attacks and MBL gene polymorphism in patients undergoing peritoneal dialysis.

Keywords: Peritoneal dialysis, peritonitis, mannose-binding lectin, $P C R$

öz

Amaç: Bu çalışmada, periton diyalizi yapılan hastalarda peritonit ataklarının mannoz bağlayan lektin (MBL) gen polimorfizimi ile arasındaki ilişki incelenmiştir.

Yöntem: MBL geni ekson 1'inde bulunan Codon 54 polimorfizmi, periton diyalizi yapılan 45 KBY hastasında ve 45 sağlıklı kontrol grubunda polimeraz zincir reaksiyonu kısıtlama fragman uzunluğu polimorfizm yöntemi ile araştırıldı.

Bulgular: Mutant B allel sıklığı hasta grubunda (\%4.4) kontrol grubuna (\%2.1) göre anlamlı derecede yüksek değildi. AB genotipi, hasta grubunda ve sağlıklı kontrol grubunda sırasıyla \%15,6 ve \% 34 olarak bulundu. Periton diyalizi yapılan çocukların\% 80'inde ve sağlıkı kontrol grubunun \%63.8'ünde AA genotipi bulundu.

Sonuç: Çalışmamızda periton diyalizi yapılan hastalarda peritonit atakları ile mannoz bağlayan lektin (MBL) gen polimorfizmi arasındaki ilişki bulunamamıştır.

Anahtar kelimeler: Periton diyalizi, peritonit, mannoz bağlayan lektin, PCR
Received: 21.09 .2020

Accepted: 31.01 .2021

Published Online: 03.08.2021

Cite as: Evren $G$, Bak M, Serdaroğlu E, Durmaz B. Özkinay F. Does mannose-binding lectin gene polymorphism in pediatric patients undergoing peritoneal dialysis cause susceptibility to the development of peritonitis? Izmir Dr. Behçet $\mathrm{Uz}$ Çocuk Hast. Dergisi. 2021;11(2):133-8.

Gültaç Evren
Dokuz Eylül Üniversite Hastanesi,
Çocuk Yoğun Bakım Ünitesi,
İzmir, Türkiye
gultacevren@gmail.com
ORCıD: 0000-0002-0614-0894
M. Bak 0000-0002-0383-5623
E. Serdaroğlu 0000-0002-6863-8866
S.B.Ü. Dr. Behçet Uz Çocuk Hastalıkları
Ve Cerrahisi Eğitim ve Araştırma
Hastanesi, Çocuk Nefroloji Kliniği
İzmir, Türkiye

B. Durmaz 0000-0002-6971-7996
F. Özkinay 0000-0001-7542-7787
Ege Üniversitesi Hastanesi,
Medikal Genetik Kliniği,
Izmir, Türkiye

\section{INTRODUCTION}

Peritoneal dialysis is one of the renal replacement treatments used in patients with chronic renal failure (CRF). In patients undergoing peritonitis CRF is a common complication of peritoneal dialysis, which is caused by microorganisms that reach hematogenously or by other means into the peritoneal cavity through the catheter lumen. It is important to detect and treat a predisposition to peritonitis, as inability to use or remove the catheter inserted into the peritoneal cavity may lead to conversion to hemodialysis, temporary loss of ultrafiltration, permanent membrane damage, and morbidity and

(C) Copyright izmir Dr. Behçet Uz Children's Hospital. This journal published by Logos Medical Publishing.

Licenced by Creative Commons 4.0 International (CC BY) 
mortality ${ }^{(1)}$. In children undergoing peritoneal dialysis, the factors that predispose them to the development of peritonitis are very important in terms of the prognosis of the patients. In the literature, mannose-binding lectin (MBL) gene polymorphism is emphasized among the variables that predispose patients undergoing peritoneal dialysis to the development of peritonitis ${ }^{(2)}$.

$M B L$ is a calcium-bound C-type lectin that acts as the primary defense mechanism against infections. A wide variety of bacteria, fungi, viruses, and parasitic organisms have connections to MBL.3 MBL plays an important role in host defense, and in cases of deficiency, and it creates a predisposition to infections caused by Neisseria meningitidis, Haemophilus influenzae, human immunodeficiency virus (HIV), influenza A, herpes simplex virus, Candida albicans, Saccharomyces cerevisiae, and Aspergillus fumigatus. The frequency of the MBL variant allele was also evaluated in pediatric patients with infections and suspected immunodeficiency (4.5). MBL gene polymorphism and MBL deficiency conditions are common and predispose to various infectious diseases. Strong relationships with serious bacterial infections have been demonstrated in patients with neutropenia or meningococcal meningitis ${ }^{(6)}$. In a study of premature infants, a relationship was found between the MBL2 gene polymorphism and gramnegative late-onset sepsis ${ }^{(7)}$.

There is very little research on the relationship between MBL gene polymorphism and predisposition to the development of peritonitis in pediatric patients undergoing peritoneal dialysis. The few relevant studies present in the literature have stated that mannose-binding lectin (MBL2) and ficolin-2 (FCN2) gene polymorphisms may predispose to peritonitis in patients undergoing peritoneal dialysis ${ }^{(2)}$. It was also suggested that MBL gene polymorphism may be the primary factor for the development of peritonitis in peritoneal dialysis patients ${ }^{(2)}$. In this study, our aim was to investigate the relationship between $\mathrm{MBL}$ codon 54 polymorphism (Gly/Asp or A/B) (rs1800450) and the development of peritonitis in patients undergoing peritoneal dialysis as suggested by several authors in the literature.

\section{MATERIALS and METHODS}

\section{Diagnosis}

This study was conducted in Izmir, Turkey, in the Dialysis Units of Dr. Behçet Uz Pediatric Diseases and Surgery Training and Research Hospital. A total of 45 patients with CRF undergoing peritoneal dialysis (22 females, 23 males) and 45 healthy controls were enrolled in the study. The diagnosis of peritonitis was based on the presence of diagnostic criteria proposed by the International Society for Peritoneal Dialysis (ISPD) as follows: 1) peritonitis-related clinical features, abdominal pain, and/or turbid dialysate fluid; 2 ) more than $100 \mathrm{WBC} / \mu \mathrm{L}$ in dialysate fluid or more than $50 \%$ polymorphonuclear cells; 3 ) detection of active microorganisms in dialysate fluid or culture. Patients were diagnosed with peritonitis when at least two of these criteria were present. Age, gender, number of peritonitis episodes, clinical findings, underlying primary disease, peritoneal dialysis method, and MBL mutations were studied in patients included in the study.

\section{Molecular Analysis}

In the DNA obtained from the peripheral blood of the patient and control groups, the codon 54 polymorphism of exon 1 of the MBL2 gene was investigated by the restriction fragment length polymorphism (RFLP) method (separation of DNA into fragments of different sizes using restriction enzymes). The first exon of the MBL gene was amplified by PCR (349 bp). Primer sequences were 5'-TAGGACAGAGGGCATGCTC-3' (F) and inverse 5'-CAGGCAGTTTCCTCTGGAAGG-3' (R). The PCR product was obtained at $94^{\circ} \mathrm{C}$ for 30 seconds after denaturation at $94{ }^{\circ} \mathrm{C}$ for 10 minutes, $57^{\circ} \mathrm{C}$ for 30 seconds, and 72 cycles of $72^{\circ} \mathrm{C}$ for 45 seconds with final holding at $7^{\circ} \mathrm{C}$ for 7 minutes. The PCR product thus obtained was kept at $50^{\circ} \mathrm{C}$ for 60 minutes with $5 \mathrm{IU}$ of Banl restriction enzyme. The normal allele (allele A) of Banl was cut into two parts of $260 \mathrm{bp}$ and $89 \mathrm{bp}$, while the variant allele (allele $B$ ) remained uncut. The products obtained were visualized by electrophoresis on $2 \%$ agarose gel. 
G. Evren et al. Does Mannose-Binding Lectin Gene Polymorphism in Pediatric Patients Undergoing Peritoneal Dialysis Cause Susceptibility to the Development of Peritonitis?

\section{Statistical Analysis}

Statistical analysis was performed using SPSS 15.0 software (SPSS Inc., Chicago, IL, USA). MBL genotype frequencies were compared by chi-square test, where $p<0.05$ was considered significant. ANOVA testing was used for comparison of numerical parameters between variables with multiple groups, and the Kruskal-Wallis test was used for those variables that did not have multiple groups. Linear and binary logistic regression analyses were used to investigate the frequency and the causative factors of peritonitis.

\section{RESULTS}

A total of 45 patients including 23 (51.1\%) boys and 22 (48.9\%) girls, who underwent peritoneal dialysis with the diagnosis of CRF were included in this study. The mean ages at the time of diagnosis were $11.19 \pm 5.56$, and $10.50 \pm 4.13$ years in those who

Table 1. Demographic characteristics of patients undergoing peritoneal dialysis with the diagnosis of CRF.

\begin{tabular}{|c|c|}
\hline Parameters & CRF cases \\
\hline Gender (girls/boys) & $22 / 23$ \\
\hline \multicolumn{2}{|l|}{ Age of onset (years) } \\
\hline Peritonitis & $11.19 \pm 5.56(\min -\max : 1-20)$ \\
\hline No peritonitis & $10.50 \pm 4.13$ (mix-max: 0-16) \\
\hline Fever & $11(24.4 \%)$ \\
\hline Abdominal pain & $20(44.4 \%)$ \\
\hline Nausea-vomiting & $12(26.7 \%)$ \\
\hline Turbid liquid & $26(57.8 \%)$ \\
\hline \multicolumn{2}{|l|}{ Origin score } \\
\hline 0 & $40(88.9 \%)$ \\
\hline 1 & $5(11.1 \%)$ \\
\hline \multicolumn{2}{|l|}{ Primary disease } \\
\hline Alport syndrome & $2(4.4 \%)$ \\
\hline Dysplasia/hypoplasia & $7(15.6 \%)$ \\
\hline Nephrotic syndrome & $8(17.8 \%)$ \\
\hline Neurogenic bladder & $6(13.3 \%)$ \\
\hline Posterior urethral valve & $5(11.1 \%)$ \\
\hline Vesicoureteral reflux & $11(24.4 \%)$ \\
\hline Other & $6(13.3 \%)$ \\
\hline Albumin & $3.511 \pm 0.6624(\min -\max : 1.5-5.7)$ \\
\hline \multicolumn{2}{|l|}{ Dialysis method } \\
\hline APD & $4(8.9 \%)$ \\
\hline CAPD & $33(73.3 \%)$ \\
\hline CCPD & $5(11.1 \%)$ \\
\hline NIPD & $3(6.7 \%)$ \\
\hline
\end{tabular}

*APD: Automated peritoneal dialysis, CAPD: continuous ambulatory peritoneal dialysis, CCPD: continuous cycling peritoneal dialysis, NIPD: nocturnal intermittent peritoneal dialysis. had, and had not peritonitis, respectively. Sixty percent $(n=27)$ of the patients had a history of peritonitis. At least one episode of peritonitis was experienced by 9 , and at most 7 episodes by 2 patients. Etiologic factors of CRF were vesicoureteral reflux in 11 (24.4\%), nephrotic syndrome in 8 (17.8\%), dysplasia/hypoplasia in 7 (15.6\%), neurogenic bladder in $6(13.3 \%)$, posterior urethral valve in $5(11.1 \%)$ and Alport syndrome in 2 (4.4\%) patients, while no etiological factor was found in 6 (13.3\%) patients. Sixty-nine peritoneal fluid cultures obtained from patients with peritonitis revealed the presence of E. coli in 7 (10.1\%), Enterobacter in $3(4.3 \%)$, Pseudomonas in $3(4.3 \%)$, and S. aureus in $2(2.9 \%)$ patients, while in $54(78.3 \%)$ patients bacterial reproduction was not detected in culture (Table 1).

While AA (normal allele), AB (homozygous allele), and $\mathrm{BB}$ (variant allele) MBL codon 54 polymorphism were determined in exon 1 at rates of $80 \%, 15.6 \%$, and $4.4 \%$ in children undergoing peritoneal dialysis due to $C R F$, the corresponding rates were $62.8 \%$, $33 \%$, and $2.1 \%$ in the control group. Thus, in terms of codon 54 polymorphism in exon 1, no statistically significant difference was found between the patient and the control groups $(p=0.113)$ (Table 2$)$.

When the association between peritonitis infection and $\mathrm{MBL}$ gene mutation was investigated, history of peritonitis was revealed in 19 (70.4\%) patients with $A A, 7$ (25.9\%) with $A B$, and 1 (3.7\%) with $\mathrm{BB}$ polymorphisms. However any statistically significant relationship was not detected between history of peritonitis and the presence of a MBL mutation ( $p=0.630$ ) (Table 3).

Table 2. Distribution of MBL gene polymorphism in patients on dialysis due to CRF and children in the control group.

\begin{tabular}{lccc}
\hline MBL gene polymorphism & $\begin{array}{c}\text { CRF } \\
(\mathbf{n}=45)\end{array}$ & $\begin{array}{c}\text { Control } \\
(\mathbf{n}=\mathbf{4 5})\end{array}$ & $\mathbf{p}$ value \\
\hline AA & $80 \%(36)$ & $62.8 \%(29)$ & 0.113 \\
AB & $15.6 \%(7)$ & $33 \%(15)$ & \\
BB & $4.4 \%(2)$ & $2.1 \%(1)$ &
\end{tabular}

*APD: Automated peritoneal dialysis, CAPD: continuous ambulatory peritoneal dialysis, CCPD: continuous cycling peritoneal dialysis, NIPD: nocturnal intermittent peritoneal dialysis. 
Table 3. Relationship between peritonitis and MBL mutation.

\begin{tabular}{lccc}
\hline MBL gene polymorphism & Peritonitis & $\begin{array}{c}\text { No } \\
\text { peritonitis }\end{array}$ & p value \\
\hline AA $(n=36)$ & $70.4 \%(19)$ & $94.4 \%(17)$ & 0.630 \\
AB $(n=7)$ & $25.9 \%(7)$ & 0 & \\
BB $(n=2)$ & $3.7 \%(1)$ & $5.6 \%(1)$ & \\
& & & \\
\hline
\end{tabular}

*APD: Automated peritoneal dialysis, CAPD: continuous ambulatory peritoneal dialysis, CCPD: continuous cycling peritoneal dialysis, NIPD: nocturnal intermittent peritoneal dialysis.

\section{DISCUSSION}

The MBL defect was first described in cases of primary opsonization disorder in 1989. Ip.W.K et al. revealed the presence of strong association between $M B L$ deficiency, low MBL levels and three missense mutations in codons 52, 54, and 57 of exon 1 in the human MBL gene. These mutations cause disruption in MBL multimerization, decrease ligand binding, and inhibit activation of the complement. Polymorphism was detected in the promoter region of $M B L$, referred to as $H / L, X / Y$, and $P / Q$ at positions $-550,-221$, and +4 , respectively. HYP causes medium and high amounts of MBL production, while LXP causes low amounts of MBL production. Five percent of people have MBL deficiency and are homozygous or heterozygous for this three-point mutation. MBL deficiency is not a classic primary immunodeficiency. There are several other mutations with significantly lower clinical penetration ${ }^{(9)}$. It has been reported in the literature that the third pathway of the complement system, the lectin cascade is initiated by $\mathrm{MBL}$, and $\mathrm{MBL}$ gene polymorphism may predispose to infections and autoimmunity ${ }^{(10)}$.

Studies have reported that MBL deficiency increases the tendency to infections, especially when comparing different alleles observed in cases of lower and upper respiratory tract infections. For example, high MBL levels have been reported to be important in preventing sepsis and septic shock. Low levels of MBL have been associated with the development of pneumonia and bacteremia in chemotherapy patients with suppressed cellular immunity, and they were also found to extend the duration of neutropenic fever. It has been reported that $\mathrm{MBL}$ plays an important role in the host defense against $N$. meningitidis, $H$. influenzae, $H I V$, influenza $A$, herpes simplex virus, $C$. albicans, $S$. cerevisiae, and $A$. fumigatus, and its deficiency has been described in infections caused by these agents ${ }^{(11,12)}$. In a study on the relationship between neonatal gram-negative sepsis and $M B L, M B L$ levels were found to be low in patients who died with septic shock compared to patients with severe sepsis, whereas there was no relationship with MBL levels in terms of early- or late-onset sepsis ${ }^{(13)}$. In a 9-year observational study conducted by Adrian et al., when dialysis and kidney grafts were compared, no relationship was found between the groups in terms of infection, cardiovascular disease, or development of mortality (14). When the effects of serum MBL concentrations and $\mathrm{MBL}$ codon 54 mutation as risk factors in patients with peritonitis were examined, serum MBL levels of peritoneal dialysis patients with mutation were found to be lower compared to hemodialysis patients with the same gene mutation. It has been suggested that the lower MBL level may be the primary factor for the development of peritonitis in peritoneal dialysis patients ${ }^{(15)}$. For this reason, we found it appropriate to investigate this subject since we thought that MBL gene polymorphism may cause a predisposition to the development of peritonitis infection in patients undergoing peritoneal dialysis.

In our study, codon 54 (allele B) polymorphism in the first exon of the MBL gene, its distribution, and its effects on clinical laboratory findings, the frequency of peritonitis, and other related factors were evaluated. $A A$ (normal allele), $A B$, and $B B$ (variant allele) gene frequencies were $80 \%, 15.6 \%$, and $4.4 \%$, respectively in the group undergoing peritoneal dialysis due to CRF. No significant difference was found in terms of gene polymorphism in patients undergoing peritoneal dialysis when compared with the control group $(p>0.05)$. The infectious origin at the onset of the disease was evaluated considering that there may be a predisposition to MBL-defect-related infection in those with MBL gene polymorphisms; however, there was no statistically significant difference in terms of peritonitis between the $A B$ (heterozygous) 
and BB (homozygous) groups with polymorphism and the AA (normal allele) group without polymorphism $(p>0.05)$. In patients who underwent peritoneal dialysis, no significant difference was found in terms of susceptibility to peritonitis and MBL gene polymorphism.

Similar to our study, in the study conducted by Erken et al., no significant difference was found between MBL levels between those who had and had not peritonitis among cases with chronic peritoneal dialysis. Though any statistically significant intergroup difference was not reported, greater number of episodes of peritonitis were found in patients with MBL deficiency, when compared with those without ${ }^{(17)}$. Lam et al., divided their study patients who developed end-stage renal failure into four groups as follows: Group 1: patients who had two or more episodes of peritonitis; Group 2: patients without history of peritonitis; Group 3: patients who underwent hemodialysis, and Group 4: patients who underwent hemodialysis due to the faulty application technique used for peritoneal dialysis. Only 28 of 120 patients who underwent peritoneal dialysis had codon 54 gene mutations, of which only 2 patients had homozygous mutations while the other patients had heterozygous mutations. Although the rate of codon 54 mutations seen in patients undergoing dialysis was similar to the rate among healthy individuals, the MBL level was found to be lower in dialysis patients. Low levels of serum MBL of dialysis patients were found to be independent of $M B L$ gene mutation and dialysis treatment method. Serum MBL levels of peritoneal dialysis patients with codon 54 point mutations were found to be lower compared to those of hemodialysis patients with the same gene mutation. There was no significant difference in terms of $\mathrm{MBL}$ codon 54 gene mutation in patients who experienced recurrent episodes of peritonitis, who underwent peritoneal dialysis, and who had not experienced attacks of peritonitis. There was also no difference between the four studied groups in terms of serum MBL levels or codon 54 point mutation ${ }^{(9)}$.

In our study, fluid turbidity, nausea-vomiting, fever, abdominal pain, low albumin levels, peritoneal dialysis method, primary disease, and MBL gene polymorphism were not found to be significant determinants in the patient group ( $p>0.05)$. It was observed that MBL gene polymorphism had no effect on the development of peritonitis, and the presence of polymorphism did not lead to the presence of more severe laboratory and clinical findings. In our study, the BB allele mutation was positive in two dialysis patients, while it was positive in one control group patient.

As suggested by several authors the absence of a significant correlation between peritonitis and serum $M B L$ levels does not exclude the importance of $M B L$ in defense immunity in peritoneal dialysis. Host defense and dialysis linkages are important determinants for peritoneal dialysis-associated peritonitis. The role played by other cytokines, complements, and toll-like receptors in such cases of peritonitis requires further investigation. Since the number of patients has increased and the rate of mutation increases as the level of MBL decreases, it would be valuable to perform new studies since the elaboration of polymorphism can give more accurate results during the period of peritonitis.

\section{CONCLUSION}

Our study has shown that, based on the results of $\mathrm{PCR}, \mathrm{MBL}$ codon 54 polymorphism mutation was not associated with the risk of experiencing peritonitis in patients undergoing peritoneal dialysis with the diagnosis of CRF. However, studies with larger patient groups may elucidate the role of MBL mutation in the etiology of peritonitis in patients undergoing peritoneal dialysis.

Ethics Committee Approval: Ethics committee approval S.B.U. It was obtained from the ethics committee of Behçet Uz Pediatric Diseases and Surgery Training and Research Hospital.

Conflict of Interest: None.

Funding: None.

Informed Consent: Obtained. 


\section{REFERENCES}

1. Burkart MD. Clinical manifestations and diagnosis of peritonitis in peritoneal dialysis. In: UpToDate, Post, TW (Ed), UpToDate, Waltham, MA, 2019.

2. Lam MF, Leung JC, Tang CC, et al. Mannose binding lectin level and polymorphism in patients on long-term peritoneal dialysis. Nephrol Dial Transplant. 2005;20:2489-96. https://doi.org/10.1093/ndt/gfi089

3. Kilpatrick DC. Mannan-binding lectin: clinical significance and applications. Biochim Biophys Acta. 2002;1572(2-3):40113. https://doi.org/10.1016/S0304-4165(02)00321-5

4. Terai I, Kobayashi K, Matsushita M, Miyakawa H, Mafune N, Kikuta H. Relationship between gene polymorphisms of mannose-binding lectin (MBL) and two molecular forms of MBL. Eur J Immunol. 2003;33(10):2755-63. https://doi.org/10.1002/eji.200323955

5. Eisen DP, Minchinton RM. Impact of mannose-binding lectin on susceptibility. Clin Infect Dis. 2003;37(11):1496-505. https://doi.org/10.1086/379324

6. Dogan P, Ozkan H, Koksal N, et al. Mannose-Binding Lectin Levels in Late-Onset Sepsis in Preterm Infants: Results from a Prospective Study in a Tertiary Care Center. Fetal Pediatr Pathol. 2020;39(5):363-72. https://doi.org/10.1080/15513815.2019.1652374

7. Meijvis S, Herpers B, Endeman $H$, de Jong $B$, van Hannen E et al. Mannose-binding lectin (MBL2) and ficolin-2 (FCN2) polymorphisms in patients on peritoneal dialysis with staphylococcal peritonitis. Nephrol Dial Transplant. 2011;26:1042-5. https://doi.org/10.1093/ndt/gfq474

8. Madsen H, Garred P, Thiel S, et al. Interplay between promoter and structural gene variants control basal serum level of mannan-binding protein. J Immunol. 1995; 15;155(6):3013-20.

9. Super M, Thiel S, Lu J, Levinsky R, Turner M. Association of low levels of mannan-binding protein with a common defect of opsonisation. Lancet. 1989; 25;2(8674):1236-9. https://doi.org/10.1016/S0140-6736(89)91849-7

10. Tsutsumi A, Takahashi R, Sumida T. Mannose binding lectin: Genetics and autoimmune disease. Autoimmunity Reviews. 2005;364-372. https://doi.org/10.1016/j.autrev.2005.02.004

11. Port RE, Ding RW, Fies T, Scharer K. Predicting the time course of haemoglobin in children treated with erythropoietin for renal anemia. Br J Clin Pharmacol. 1998;46(5):461-6. https://doi.org/10.1046/j.1365-2125.1998.00797.x

12. Wahab Mohamed WA, Saeed MA. Mannose-binding lectin serum levels in neonatal sepsis and septic shock. J Matern Fetal Neonatal Med. 2012;25(4):411-4 https://doi.org/10.3109/14767058.2011.582903

13. Adrian $T$, Hornum $M$, Eriksson $F$, et al. Mannose-binding lectin genotypes and outcome in end-stage renal disease: a prospective cohort study. Nephrol Dial Transplant. 2018; 1;33(11):1991-7. https://doi.org/10.1093/ndt/gfy034

14. Sanchez C, Salusky I. The renal bone diseases in children treated with dialysis. Adv Ren Replace Ther. 1996;3(1):1423. https://doi.org/10.1016/S1073-4449(96)80037-9

15. Erken E, Torun D, Sezgin N, et al. The effect of serum mannose-binding lectin levels on dialysis-related peritonitis and catheter-related bacteremia. Turkish J Nephrol. 2015;24:189-94.

https://doi.org/10.5262/tndt.2015.1002.08 